\title{
Relationship between Hybridoma Screening Procedures and the Characteristics of Monoclonal Antibodies for Use in Direct Double Antibody Sandwich ELISA for the Detection of Plant Viruses*
}

\author{
Kazusato OHSHIMA**, Jumanto HarJosudarmo**, Yo IsHIKAWA** \\ and Eishiro SHIKATA**
}

\begin{abstract}
More than two hundred and fifty-five monoclonal antibody (MoAb)-secreting hybridomas against 3 plant luteoviruses, 2 plant reoviruses and a potyvirus were produced. The hybridomas for potato leafroll virus, beet western yellows virus, tobacco necrotic dwarf virus, rice dwarf virus, rice ragged stunt virus and potato virus $\mathrm{Y}$-ordinary strain, were screened by four different procedures of enzyme-linked immunosorbent assay (ELISA); procedure 1, antigen adsorption indirect ELISA (AAI-ELISA) in which purified virus in phosphate buffered saline (PBS) at pH 7.4 was adsorbed onto the microplate wells, procedure 2, AAI-ELISA in which purified virus in sodium carbonate-bicarbonate buffer at $\mathrm{pH} 9.6$ was adsorbed onto the microplate wells, procedure 3 , indirect double antibody sandwich ELISA (IDAS-ELISA) in which polyclonal antibody was used as trapping antibody and purified virus preparations diluted in PBS-T (containing Tween-20) as antigens were used, procedure 4, IDAS-ELISA in which polyclonal antibody was used for trapping antibody and crude saps of virus infected plants extracted in PBS-T as antigens were used. Based on the MoAb reactivities against homologous viruses in four different ELISA procedures, MoAb-secreting hybridomas were divided into ten groups. Using purified MoAbs from ascitic 'fluids, direct double antibody sandwich ELISA (DAS-ELISA) was examined for the detection of virus antigens in infected plants. All the MoAbs reacted in DAS-ELISA belonged to group 1 in which the MoAbs were reactive in each four of the screening procedures $1-4$, or group 2 lin which MoAbs were reactive in three of screening procedures 1,3 and 4. These results indicate that MoAbs being reactive in DAS-ELISA can be readily selected in hybridomas in group 1 or 2.
\end{abstract}

(Received January 5, 1990)

Key words: monoclonal antibody, plant virus, screening, DAS-ELISA.

\section{INTRODUCTION}

The hybridoma technology introduced by Köhler and Milstein ${ }^{6}$ ) has provided a revolutionary advance in the serological techniques that eliminates problems associated with polyclonal antibody (PoAb). Halk and De Boer ${ }^{3)}$ mentioned that monoclonal antibodies (MoAbs) offer several advantages over conventional PoAbs: (a) MoAb-secreting hybridomas can be preserved by freezing in liquid nitrogen, thereby assuring a continuous supply of antibody over time; (b) the use of MoAbs eliminates the qualitative and quantitative variability in specific antibody content in different batches of PoAbs.

* This work was supported in part by Grant-in-Aid Encouragement of Young Scientists (No. 01760039) from the Ministry of Education, Science and Culture of Japan.

** Department of Botany, Faculty of Agriculture, Hokkaido University, Kita 9, Nishi 9, Kita-ku, Sapporo 060, Japan 北海道大学農学部 
In the application of MoAbs in enzyme-linked immunosorbent assay (ELISA) for viral detection in infected plants, indirect double antibody sandwich ELISA (IDAS-ELISA) using PoAbs as trapping antibody has been mostly employed ${ }^{5,7,11,13,14)}$. The disadvantage of this system is that the PoAbs must be prepared in addition to the MoAbs. On the other hand, direct double antibody sandwich ELISA (DAS-ELISA) using MoAb both for trapping antibody and for enzyme conjugate was scarcely applied so far ${ }^{2,10,14)}$.

In this paper, we report production of MoAbs against 3 luteoviruses, 2 plant reoviruses and a potyvirus, and compared four different indirect ELISA procedures as indicated in Table 1 for screening hybridomas ${ }^{2,4,7-10,13,14}$ which secrete MoAb applicable to DAS-ELISA.

\section{MATERIALS AND METHODS}

Viruses. Tobacco necrotic dwarf virus (TNDV) was kindly provided by Dr. S. Kubo, Japan Tobacco Inc. TNDV, potato leafroll virus (PLRV) and beet western yellows virus (BWYV) were maintained in Physalis floridana plants, rice dwarf virus (RDV) and rice ragged stunt virus (RRSV) were maintained in rice plants and potato virus Y-ordinary strain (PVY-O) was maintained in Nicotiana sylvestris plants, under a greenhouse condition.

Virus purification. Purification of the viruses was carried out by the methods previously described for PLRV, BWYV and TNDV ${ }^{10)}$, for $\mathrm{RDV}^{15)}$, for RRSV ${ }^{16)}$ and for PVY$\mathrm{O}^{17)}$. Virus concentration was estimated from absorbance at $260 \mathrm{~nm}$, assuring that $1 \mathrm{mg}$ of the virus corresponds to $8.6 A_{26}$ units for luteoviruses, $5.0 A_{260}$ units for plant reoviruses and $2.3 A_{260}$ units for a potyvirus, respectively.

Crude saps. One gram of the virus-infected or healthy plants were homogenized in $5 \mathrm{ml}$ of phosphate buffered saline (PBS) $\left(40 \mathrm{~g} \mathrm{NaCl}, 1 \mathrm{~g} \mathrm{KH}_{2} \mathrm{PO}_{4}, 14.5 \mathrm{~g} \mathrm{NaHPO} \cdot 12 \mathrm{H}_{2} \mathrm{O}, 1 \mathrm{~g}\right.$ $\mathrm{KCl}, 1 \mathrm{~g} \mathrm{NaN}_{3}$ per 1 liter distilled water, $\mathrm{pH}$ 7.4) containing $0.05 \%$ Tween 20 (PBS-T).

Production of polyclonal antibodies. Rabbits were immunized by subcutaneous injections with 40-100 $\mu \mathrm{g}$ of purified virus emulsified with Freund's complete adjuvant twice and a booster was carried out by an intravenous injection with one hundred $\mu \mathrm{g}$ of the viruses.

\section{Production of monoclonal antibodies.}

1) Immunization Four to six weeks-aged BALB/c mice were used for immunization. Immunizations were carried out by direct injection to the spleen ${ }^{12)}$ with the purified virus in $0.01 \mathrm{M}$ PBS at pH 7.0, four days before hybridization.

2) Hybridization SP2/0-Ag 14 cells were grown exponentially in Dulbecco's modified Eagle's medium (DMEM), consisting of $0.584 \mathrm{~g}$ L-glutamine, $200 \mathrm{mg}$ Kanamycin,

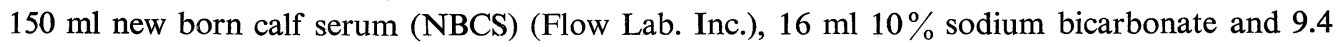
g powdered DMEM (Nissui 2, Nissui Pharmaceutical Co., Inc.) per liter, pH 7.2, and sterilized by filtration or autoclaving.

Hybridizations $^{1)}$ were carried out by mixing $1.0 \times 10^{8}$ spleen cells with $1.0 \times 10^{7} \mathrm{SP} 2 / 0$ cells and fused them using PEG \#1,000 (Kanto Chem. Co., Inc.). The cells were cultured under HAT-DME selective medium ( $0.1 \mathrm{mM}$ hypoxantine, $0.42 \mu \mathrm{M}$ aminopterin, $64 \mu \mathrm{M}$ tymidine) in 96-well tissue culture plates (Nunc) and were incubated at $37 \mathrm{C}$ in $5 \% \mathrm{CO}_{2}$ in air. Two, 4 and 10 days after the hybridization, the HAT-DME selective medium was added. Two weeks after the hybridization, the cell-free culture fluids were screened (first screening) for the presence of antibodies against the viruses using four different ELISA procedures (see screening procedures).

3) Collection of hybridomas Afteri the first screening, antibody secreting hybridomas which colonized from single cell in a well were transferred to 24-well plates (NUNC), then hybridomas were transferred to $6-\mathrm{cm}$ petri dishes. Before hybridomas were saturated in the petri dishes, these were collected by low speed centrifugation and frozen with $90 \%$ NBCS containing $10 \%$ dimethylsulfoxide (Nakarai Tesque, Inc.) in liquid nitrogen. And culture fluids for second screening with four different ELISA were stocked at $-30 \mathrm{C}$. The absorbance 
values obtained in first screening were almost similar to those obtained in second screening, so that the data shown in Table 2 were results obtained from the second screening.

4) Screening procedures Screening procedures used in the experiments are shown in Table 1. Four types of enzyme-linked immunosorbent assay (ELISA) procedures were used in the screening.

In antigen adsorption indirect ELISA (AAI-ELISA), ninety-six wells of polystylene plates (Nunc, Immunoplate II) were coated with $0.5 \mu \mathrm{g} / \mathrm{ml}$ viruses in $200 \mu \mathrm{l}$ of $0.02 \mathrm{M} \mathrm{PBS}, \mathrm{pH} 7.4$ (procedure 1) or $0.05 \mathrm{M}$ sodium carbonate-bicarbonate buffer (SCB), $\mathrm{pH} 9.6$ (procedure 2), and incubated for $12 \mathrm{hr}$ at $4 \mathrm{C}$. Plates were washed with PBS-T and then cultured fluids were added and they were incubated for $3 \mathrm{hr}$ at $37 \mathrm{C}$. After washing, alkaline phosphataselabelled goat anti-mouse Ig enzyme conjugate (Zymed Lab. Inc.) was used at 1,000-fold dilution in PBS-T was added and the plates were incubated for $3 \mathrm{hr}$ at $37 \mathrm{C}$. Substrate ( $p$-nitrophenylphosphate) after washing and hydrolysis time was for $1 \mathrm{hr}$ at room temperature.

In indirect double antibody sandwich ELISA (IDAS-ELISA), polyclonal antibodies (PoAbs) were used for the 1st (trapping) antibody at the concentration of $2 \mu \mathrm{g} / \mathrm{ml}$. After incubation for $3 \mathrm{hr}$ at $37 \mathrm{C}, 0.5 \mu \mathrm{g} / \mathrm{ml}$ purified virus (procedure 3 ) or crude saps of virus infected plants (procedure 4) were added and they were incubated for $12 \mathrm{hr}$ at $4 \mathrm{C}$. Then culture fluids were incubated for $3 \mathrm{hr}$ at $37 \mathrm{C}$ and anti-mouse Ig enzyme conjugate was added and they were incubated for $3 \mathrm{hr}$ at $37 \mathrm{C}$. Substrate was added after washing and hydrolysis time was for 1 $\mathrm{hr}$ at room temperature. The absorbance of each well was measured at $A_{415}$ with Corona MTP-100.

5) Production of ascitic fluids Ascitic fluids were produced by intraperitoneal inoculation of $5 \times 10^{5}$ to $1 \times 10^{6}$ hybridomas into synegenic BALB/c mice which were injected by $0.5 \mathrm{ml}$ pristane $(2,6,10,14$-tetramethylpentadecane) 2 weeks before inoculation.

Purification of antibodies. PoAbs and MoAbs were purified from ascitic fluids using ammonium sulphate precipitation and DEAE cellulose column chromatography (DE 32, Whatman Ltd. $)^{10)}$. Purified antibodies were conjugated with alkaline phosphatase described by Ohshima et al. ${ }^{10)}$

Detection of viruses by DAS-ELISA. As shown in Table 1, direct double antibody sandwich ELISA (DAS-ELISA) was used to detect virus in crude saps (procedure 5). Trapping MoAbs purified from ascitic fluids were used at the concentration of $5-10 \mu \mathrm{g} / \mathrm{ml}$. After incubation for $3 \mathrm{hr}$ at $37 \mathrm{C}$, crude saps of virus infected plants were added and they were incubated for $12 \mathrm{hr}$ at $4 \mathrm{C}$. Then 200-800-fold dilution of enzyme conjugates (2nd MoAbs)

Table 1. Procedures of ELISA a)

\begin{tabular}{|c|c|c|c|c|c|}
\hline \multirow{2}{*}{ AAI-ELISA } & \multicolumn{5}{|c|}{ Step } \\
\hline & \multicolumn{2}{|r|}{$1 \mathrm{st}$} & \multicolumn{2}{|c|}{ 2nd } & $3 \mathrm{rd}$ \\
\hline \multirow{3}{*}{$\begin{array}{l}\text { Procedure } 1 \\
\text { Procedure } 2\end{array}$} & \multicolumn{2}{|c|}{ Purified virus in PBS, $\mathrm{pH} 7.4$} & \multicolumn{2}{|c|}{ MoAbs } & Anti-mouse Ig EC b) \\
\hline & Purified & irus in $\mathrm{SCB}, \mathrm{pH} 9.6$ & \multicolumn{2}{|c|}{ MoAbs } & Anti-mouse Ig EC \\
\hline & \multicolumn{5}{|c|}{ Step } \\
\hline IDAS-ELISA & $1 \mathrm{st}$ & 2 nd & & $3 \mathrm{rd}$ & 4 th \\
\hline \multirow{2}{*}{$\begin{array}{l}\text { Procedure } 3 \\
\text { Procedure } 4\end{array}$} & PoAbs & \multirow{2}{*}{\multicolumn{2}{|c|}{$\begin{array}{l}\text { Purified virus in PBS-T, pH } 7.4 \\
\text { Crude sap virus in PBS-T, pH } 7.4\end{array}$}} & MoAbs & Anti-mouse Ig EC \\
\hline & PoAbs & & & MoAbs & Anti-mouse Ig EC \\
\hline \multirow{2}{*}{ DAS-ELISA } & \multicolumn{5}{|c|}{ Step } \\
\hline & $1 \mathrm{st}$ & \multicolumn{2}{|l|}{ 2nd } & $3 r d$ & \\
\hline Procedure 5 & MoAbs & \multicolumn{2}{|c|}{ Crude sap virus in PBS-T, pH 7.4} & \multicolumn{2}{|c|}{ MoAbs EC } \\
\hline
\end{tabular}

a) Procedures 1-4 were used in screening.

b) EC, enzyme conjugate. 
were added and they were incubated for $3 \mathrm{hr}$ at $37 \mathrm{C}$. Substrate was added after washing and hydrolysis time was for 1-2 $\mathrm{hr}$ at room temperature.

Ig types and titers of MoAbs. Immunoglobulin (Ig) types of MoAbs were determined by AAI-ELISA (procedure 2) described by Ohshima et al. ${ }^{9)}$ and titers of MoAbs were also determined by AAI-ELISA (procedure 2).

\section{RESULTS}

\section{Groups of hybridomas}

Table 2 shows MoAb-secreting hybridomas obtained in this experiment. They were divided into ten groups according to the reactivities to homologous viruses in four different ELISA procedures. Most (71.4-88.9\%) of MoAb-secreting hybridomas against luteoviruses belonged to group 3, where antibodies reacted only in AAI-ELISA. On the other hand, less than $7.7 \%$ of MoAb-secreting hybridomas against luteoviruses were in other groups except for those against TNDV in group 1. In case of TNDV, MoAb-secreting hybridomas were $23.8 \%$ in group 1 .

About a half of MoAb-secreting hybridomas against plant reoviruses belonged to group 1, where antibodies reacted in all four ELISA procedures. However, none of MoAb-secreting hybridomas against plant reoviruses belonged to group 3 was obtained.

About a half of MoAb-secreting hybridomas against a potyvirus belonged to group 1 . Furthermore, $25.7 \%$ of MoAb-secreting hybridomas against potyvirus belonged to group 2, where antibodies reacted both in procedure 1 of AAI-ELISA and in procedure 3 and 4 of IDASELISA.

Use of MoAbs in DAS-ELISA

MoAbs purified from ascitic fluids were examined in DAS-ELISA. As shown in Table 3, one luteovirus-MoAb (TND-1E2), two plant reovirus-MoAbs (RD-11C10 and RRS-183D07) and five potyvirus-MoAbs (PVYO-12H01, 21H05, 22D01, 42A08 and 51E04) were reacted with homologous viruses in crude saps in DAS-ELISA.

On the other hand, seven luteovirus-MoAbs, two plant reovirus-MoAbs and five potyvirus-

Table 2. Groups of monoclonal antibody-secreting hybridomas according to ELISA reactions

\begin{tabular}{|c|c|c|c|c|c|c|c|c|c|c|}
\hline \multirow{4}{*}{ Group } & \multirow{2}{*}{\multicolumn{4}{|c|}{ Screening procedurea) }} & \multicolumn{6}{|c|}{ No. of hybridomas } \\
\hline & & & & & \multicolumn{6}{|c|}{ Antigen } \\
\hline & \multicolumn{2}{|c|}{ AAI-ELISA } & \multicolumn{2}{|c|}{ IDAS-ELISA } & \multicolumn{3}{|c|}{ Leteovirus } & \multicolumn{2}{|c|}{ Plant reovirus } & \multirow{2}{*}{$\frac{\text { Potyvirus }}{\text { PVY-O }}$} \\
\hline & 1 & 2 & 3 & 4 & PLRV & BWYV & TNDV & RDV & RRSV & \\
\hline 1 & $+b)$ & + & + & + & $6(7.7)^{c)}$ & $1(2.8)$ & $5(23.8)$ & d) $13(56.5)$ & $15(48.4)$ & $55(56.7)$ \\
\hline 2 & + & - & + & + & $2(2.6)$ & $1(2.8)$ & $\overline{1(4.8)}$ & $0(0.0)$ & $\overline{0(0.0)}$ & $25(25.7)$ \\
\hline 3 & + & + & - & - & $70(89.7)$ & $32(88.9)$ & $15(71.4)$ & $0(0.0)$ & $0(0.0)$ & $0(0.0)$ \\
\hline 4 & - & - & + & + & $0(0.0)$ & $0(0.0)$ & $0(0.0)$ & $3(13.0)$ & $5(16.1)$ & $4(4.1)$ \\
\hline 5 & - & - & - & + & $0(0.0)$ & $0(0.0)$ & $0(0.0)$ & $0(0.0)$ & $5(16.1)$ & $12(12.4)$ \\
\hline 6 & + & - & - & - & $0(0.0)$ & $2(5.6)$ & $0(0.0)$ & $0(0.0)$ & $0(0.0)$ & $1(1.0)$ \\
\hline 7 & + & + & + & - & $0(0.0)$ & $0(0.0)$ & $0(0.0)$ & $1(4.3)$ & $1(3.2)$ & $0(0.0)$ \\
\hline 8 & - & + & + & + & $0(0.0)$ & $0(0.0)$ & $0(0.0)$ & $3(13.0)$ & $3(9.7)$ & $0(0.0)$ \\
\hline 9 & - & + & + & - & $0(0.0)$ & $0(0.0)$ & $0(0.0)$ & $1(4.3)$ & $2(6.5)$ & $0(0.0)$ \\
\hline \multirow[t]{2}{*}{10} & - & - & + & - & $0(0.0)$ & $0(0.0)$ & $0(0.0)$ & $2(8.7)$ & $0(0.0)$ & $0(0.0)$ \\
\hline & & & & & $78(100 \%) 3$ & $36(100 \%)$ & $21(100 \%)$ & $23(100 \%)$ & $31(100 \%)$ & $97(100 \%)$ \\
\hline
\end{tabular}

a) Screening procedures of ELISA were shown in Table 1.

b) +, antibodies of hybridomas reacted with viruses; - , antibodies of hybridomas slightly or did not reacted with the virus.

c) Number of hybridomas belonged to the group / Total number of hybridomas $(\%)$.

d) Underlines show that more than $20 \%$ of hybridomas belonged to the group. 
Table 3. Absorbance values of purified monoclonal antibodies in DAS-ELISA procedures

\begin{tabular}{|c|c|c|c|c|c|c|c|c|}
\hline \multicolumn{4}{|c|}{ Reactive in DAS-ELISA } & \multicolumn{5}{|c|}{ Not reactive in DAS-ELISA } \\
\hline \multirow{2}{*}{$\begin{array}{l}\text { Monoclonal } \\
\text { antibody b) }\end{array}$} & \multicolumn{3}{|c|}{ Absorbance $\left(A_{4.15}\right)$ a) } & \multirow{2}{*}{\multicolumn{2}{|c|}{$\begin{array}{l}\text { Monoclonal } \\
\text { antibody }\end{array}$}} & \multicolumn{3}{|c|}{ Absorbance $\left(A_{415}\right)$} \\
\hline & Infected & $\mathrm{H}^{\mathrm{c})}$ & PBS & & & Infected & $\mathrm{H}^{\mathrm{c})}$ & PBS \\
\hline TND- & 1.94 & 0.01 & 0.00 & PLR- & $11 \mathrm{~A} 09$ & 0.50 & 0.67 & 0.00 \\
\hline $11 \mathrm{C} 10$ & $2<$ & 0.03 & 0.00 & & 33E07 & 0.11 & 0.05 & 0.00 \\
\hline RRS- 183D07 & 0.68 & 0.05 & 0.00 & & $51 \mathrm{C} 01$ & 0.23 & 0.13 & 0.00 \\
\hline PVYO- $12 \mathrm{H} 01$ & 0.78 & 0.01 & 0.00 & BWY- & $21 \mathrm{G} 06$ & 0.05 & 0.03 & 0.00 \\
\hline $21 \mathrm{H} 05$ & $2<$ & 0.02 & 0.00 & TND- & 33D07 & 0.02 & 0.00 & 0.00 \\
\hline 22D01 & 1.07 & 0.00 & 0.00 & & 33E07 & 0.01 & 0.01 & 0.00 \\
\hline 42A08 & $2<$ & 0.02 & 0.00 & & 43B05 & 0.01 & 0.00 & 0.00 \\
\hline 51E04 & $2<$ & 0.03 & 0.00 & RD- & $63 \mathrm{C} 12$ & 0.12 & 0.07 & 0.00 \\
\hline & & & & RRS- & $191 \mathrm{G} 05$ & 0.23 & 0.08 & 0.00 \\
\hline & & & & PVYO- & 11C01 & 0.26 & 0.00 & 0.00 \\
\hline & & & & & $22 \mathrm{~A} 02$ & 0.00 & 0.00 & 0.00 \\
\hline & & & & & $31 \mathrm{C} 12$ & 0.01 & 0.01 & 0.00 \\
\hline & & & & & $41 \mathrm{G} 07$ & 0.02 & 0.01 & 0.00 \\
\hline & & & & & 62Е04 & 0.03 & 0.03 & 0.00 \\
\hline
\end{tabular}

a) Hydrolysis times were 1-2 $\mathrm{hr}$ at $20 \mathrm{C}$.

b) MoAbs are marked as below:

from PLRV-hybridomas, PLR-; from BWYV-hybridomas, BWY-;

from TNDV-hybridomas, TND-; from RDV-hybridomas, RD-;

from RRSV-hybridomas, RRS-; from PVY-O-hybridomas, PVYO-.

Trapping antibodies were used at the concentration of $5-10 \mu \mathrm{g} / \mathrm{ml}$ and enzyme conjugates were used at $200-800$-fold dilutions.

c) Healthy plants.

MoAbs did not react with the viruses in crude saps in DAS-ELISA.

\section{Reactivities of purified MoAbs in four ELISA procedures}

MoAbs purified from ascitic fluids were examined in four ELISA procedures.

The results shown in Table 4 indicate that MoAbs reacted in DAS-ELISA are included in groups 1 and 2. On the other hand, MoAbs which were not reacted in DAS-ELISA distributed in groups $1-5$.

\section{Ig types and titers of MoAbs}

As shown in Table 5, Ig types and titers of MoAbs obtained were determined.

Four MoAbs, such as TND-1E2, RD-11C10, PVYO-42A08 and PVYO-51E04 were IgG, and four MoAbs such as RRS-187D07, PVYO-12H01, 21H05 and 22D01 were IgM. Titers of these MoAbs which were reactive in DAS-ELISA were 1/25-1/3,125.

Ig types of MoAbs which were not reactive in DAS-ELISA were also IgG or IgM, and titers of MoAbs were 1-1/3,125.

\section{DISCUSSION}

We investigated the relationships between four different hybridoma-screening procedures of ELISA which were reported in previous papers ${ }^{2,4,7-10,13,14}$ and the characteristics of MoAbs obtained in three luteoviruses, two plant reoviruses and a potyvirus, for use in DAS-ELISA for the detection of virus antigens in infected plants.

Ten MoAbs against PLRV were produced by Massalski and Harrison ${ }^{8)}$ and the reactivity of the MoAbs with plate-trapped antigen was examined in AAI-ELISA using PLRV in either SCB at pH 9.6 or PBS pH 7.4 as the antigen. Their results showed that all the MoAbs reacted with PLRV antigen which was trapped in PBS, suggesting that all the epitopes detected were 


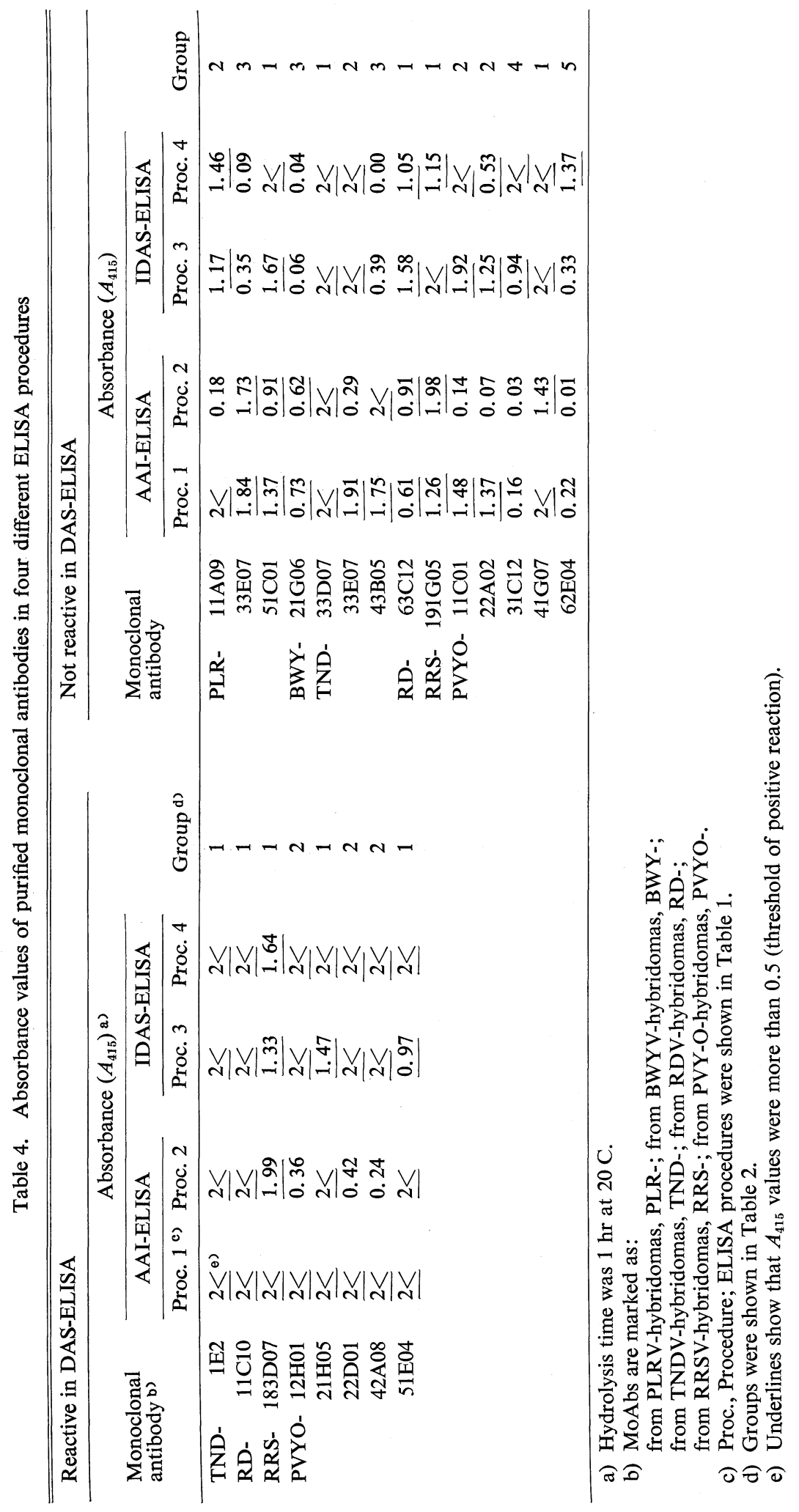


Table 5. Ig types and titers of monoclonal antibodies

\begin{tabular}{|c|c|c|c|c|c|}
\hline \multicolumn{2}{|c|}{ Reactive in DAS-ELISA } & \multirow[b]{2}{*}{ Titer } & \multicolumn{2}{|c|}{ Not reactive in DAS-ELISA } & \multirow[b]{2}{*}{ Titer } \\
\hline $\begin{array}{l}\text { Monoclonal } \\
\text { antibody }\end{array}$ & Ig type & & $\begin{array}{l}\text { Monoclonal } \\
\text { antibody }\end{array}$ & Ig type & \\
\hline TND- $\quad$ E2 a) & IgG & $625 \mathrm{~b})$ & 11A09 & $\operatorname{IgM}$ & 625 \\
\hline RD- $\quad 11 \mathrm{C} 10$ & IgG & 3,125 & 33E07 & $\operatorname{IgM}$ & 625 \\
\hline RRS- $183 \mathrm{D} 07$ & $\operatorname{IgM}$ & 625 & $51 \mathrm{C} 01$ & $\operatorname{IgM}$ & 125 \\
\hline PVYO- $12 \mathrm{H} 01$ & $\operatorname{IgM}$ & 625 & $21 \mathrm{G} 06$ & $\operatorname{IgM}$ & 5 \\
\hline $21 \mathrm{H} 05$ & $\operatorname{IgM}$ & 625 & TND- & IgG & 3,125 \\
\hline 22D01 & $\operatorname{IgM}$ & 125 & 33E07 & $\operatorname{IgM}$ & 5 \\
\hline 42A08 & IgG & 125 & $43 \mathrm{~B} 05$ & $\operatorname{IgM}$ & 125 \\
\hline $51 \mathrm{E} 04$ & IgG & 25 & $63 \mathrm{C} 12$ & IgG & 3,125 \\
\hline & & & RRS- $191 \mathrm{G} 05$ & $\operatorname{IgM}$ & 625 \\
\hline & & & PVYO- $11 \mathrm{C} 01$ & IgG & 5 \\
\hline & & & $22 \mathrm{~A} 02$ & IgG & 5 \\
\hline & & & $31 \mathrm{C} 12$ & IgG & 1 \\
\hline & & & 41G07 & $\mathrm{IgG}$ & 25 \\
\hline & & & $62 \mathrm{E} 04$ & IgG & 1 \\
\hline
\end{tabular}

a) MoAbs are marked as below:

from PLRV-hybridomas, PLR-; from BWYV-hybridomas, BWY-;

from TNDV-hybridomas, TND-; from RDV-hybridomas,RD-;

from RRSV-hybridomas, RRS-; from PVY-O-hybridomas, PVYO-.

b) Titers are demonstrated in reciprocal.

Titers were determined by procedure 2 of AAI-ELISA and Titer 1 indicates that monoclonal antibody was reacted with the virus at the concentration of $5 \mu \mathrm{g} / \mathrm{ml}$.

on the surface of virus particles. In contrast, only four MoAbs did not react or weakly reacted with PLRV antigen which was trapped in SCB, suggesting that these MoAbs probably detected epitopes dependent on quaternary structure.

As shown in Table 4, PVYO-12H01, 22D01 and 42A08 DAS-ELISA reactive MoAbs slightly reacted with virus antigen which was trapped in SCB (procedure 2), suggesting that these MoAbs probably detected epitopes dependent on quarternary structure. In contrast, all MoAbs reactive in DAS-ELISA strongly reacted with virus antigen which was trapped in PBS (procedure 1), suggesting that all the epitopes detected were on the surface of virus particles. These results indicated that MoAbs reactive in DAS-ELISA were not related with specificity for epitopes dependent on quaternary structure, but related with the epitopes on surface of virus particles. Further relations between MoAbs reactive in DAS-ELISA and the epitopes of virus particle are necessary.

Furthermore, as shown in Table 5, relations between Ig types and titers of MoAbs and MoAbs which were useful for DAS-ELISA were investigated. However, no apparent correlation between Ig types of DAS-ELISA reactive and non reactive MoAbs was found.

To summarize our data, MoAbs which were reactive in DAS-ELISA belonged to group 1 or 2 . On the other hand, MoAbs which were not reactive in DAS-ELISA belonged to groups 1-5 (Table 4). That is, MoAbs reactive in DAS-ELISA which probably recognize the epitopes on the surface of virus particles, can be readily selected in hybridomas in group 1 or 2 .

\section{Literature cited}

1. Galfré, G. and Milstein, C. (1981). Methods in Enzymology 73B: 3-46.

2. Gugerli, P. and Fries, P. (1983). J. gen. Virol. 64: 2471-2477.

3. Halk, E. and De Boer, S. (1985). Ann. Rev. Phytopath. 23: 321-350.

4. Hsu, H.T., Franssen, J.M., van der Hulst, C.T.C., Derks, A.F.L.M. and Lawson, R.H. (1988). Phytopathology 78: 1337-1340. 
5. Huss, B., Muller, S., Sommermeyer, G., Walter, B. and Van Regenmortel, M.H.V. (1987). J. Phytopathol. 119: 358-370.

6. Köhler, G. and Milstein, C. (1975). Nature, London 256: 495-497.

7. Martin, R.R. and Stace-Smith, R. (1984). Canad. J. Plant Path. 6: 206-210.

8. Massalski, P.R. and Harrison, B.D. (1987). J. gen. Virol. 68: 1813-1821.

9. Ohshima, K., Uyeda, I. and Shikata, E. (1988). J. Fac. Agr. Hokkaido Univ. 63: 373-383.

10. Ohshima, K., Uyeda, I. and Shikata, E. (1989). Ann. Phytopath. Soc. Japan 55: 420-426.

11. Rose, D.G. and Hubbard, A.L. (1986). Ann. Appl. Biol. 109: 317-321.

12. Spitz, M., Spitz, L., Thorpe, R. and Egugui, E. (1984). J. Immunol. Meth. 70: 39-43.

13. Torrance, L., Larkins, A.P. and Butcher, G.W. (1986). J. gen. Virol. 67: 57-67.

14. Torrance, L., Pead, M.T., Larkins, A.P. and Butcher, G.W. (1986). Ibid. 67: 549-556.

15. Uyeda, I. and Shikata, E. (1982). Ann. Phytopath. Soc. Japan 48: 295-300.

16. Uyeda, I., Lee, S.Y., Yoshimoto, H. and Shikata, E. (1987). Ibid. 53: 60-62.

17. Uyeda, I., Kojima, M., Yonemura, M., Aoki, T., Kawada, T. and Shikata, E. (1984). J. Fac. Agr. Hokkaido Univ. 62: 22-35.

\section{和 文 摘 要}

大島一里・Jumanto HARJOSUdARMO・石川 陽・四方英四郎 : 直接二重抗体サンドイッチ ELISA に利 用できるモノクローナル抗体を得るためのハイブリドーマのスクリーニング法の選定

255 種のモノクローナル抗体 (MoAb) 産生ハイブリドーマを 3 種の luteovirus, 2 種の plant reovirus 拉 よび 1 種の potyvirus に対して作製した。Luteovirus としてはジャガイモ葉巻ウイルス，テンサイ西部萎黄 ウイルス和よびタバコえそ萎縮ウイルス, plant reovirus としてはイネ萎縮ウイルス拉よびイネラギットス タントウイルス, potyvirus としてはジャガイモ Y ウイルスー普通系統を用い, ハイブリドーマは以下の 4 種類の異なる方法による ELISA でスクリーニングした。方法 1. 生理リン酸緩衝液 (PBS), pH 7.4 中で純 化ウイルスを直接マイクロプレートウェルに吸着させた抗原吸着間接 ELISA (AAI-ELISA), 方法 2. 炭 酸-重炭酸緩衝液，pH 9.6 中で純化ウイルスを直接マイクロプレートウエルに吸着させた AAI-ELISA，方 法 3. ポリクローナル抗体 $(\mathrm{PoAb})$ を trapping 抗体，抗原としては純化ウイルスを Tween-20を含むPBS (PBS-T), pH 7.4 中で反応させた間接二重抗体サンドイッチ ELISA (IDAS-ELISA), 方法 4. PoAb を trapping 抗体, 抗原としてはPBS-Tで搾汁したウイルス罹病葉粗汁液を反応させた IDAS-ELISAを用い た。上記 4 種類の ELISA に括ける反応に基づき，MoAb 産生ハイブリドーマを 10 グループに分けた。腹 水より得られた MoAb を精製し，スクリーニングに用いた 4 種類の ELISA を行うと, DAS-ELISA で利 用可能な MoAb は，方法 1-4 の4 種類すべての ELISA に反応するグループ 1, あるいは方法 1, 3 特よ び4 の ELISA に反応するグループ 2 に属した。以上の結果は，スクリーニングに㧤いてグループ 1 ある いは 2 に属するハイブリドーマを選抜すれば DAS-ELISA に利用可能な MoAb が得やすいことを示唆し ている。 